\title{
Record of the Arrow-headed Trinket Snake (Coelognathus helena nigriangularis) from Ranthambore Tiger Reserve, Rajasthan, India
}

\author{
Gaurav Singh ${ }^{1}$, Ankit Moun ${ }^{1}$, and Vishal Mistry ${ }^{2}$
}

'Sálim Ali Centre for Ornithology and Natural History, Anaikatty (Post), Coimbatore 641108, Tamil Nadu, India (gaurav12wl@gmail.com) 2Darbar Pole, Near Haveli, Vaso-387380, Vaso, Kheda, Gujarat, India (ankit.moun29@gmail.com; vmistry@vncindia.org)

$\mathrm{T}$ The recently described Arrow-headed Trinket Snake (Coelognathus helena nigriangularis) is characterized by an inverted black V- or Y-shaped mark on the ventrolateral side of the neck near the base of the parietal shields (Mohapattra et al. 2016; Chowdhury et al. 2018). At 1101 h on 24 November 2018, after completing a morning line transect survey (for tigers) at the Ranthambore Tiger Reserve (Sawai Madhopur District, Rajasthan), we encountered an Arrowheaded Trinket Snake (Fig. 1) coiled and basking on the main trail near the Raipur Post $\left(26.013574^{\circ} \mathrm{N}, 76.422362^{\circ} \mathrm{E}\right.$; elev. $356 \mathrm{~m}$ asl). In response to our presence, the juvenile (approx. $0.3-0.4 \mathrm{~m}$ in total length) moved into nearby leaflitter. The surrounding area was covered predominantly with Dhonk Trees (Anogeissus pendula).

Coelognathus helena nigriangularis has been recorded from parts of Odisha (Mohapattra et al. 2016), Madhya Pradesh (Edake 2011; Kumbhar et al. 2011), Jharkhand (Lampe and Lindholm 1902; Srivastava et al. 2013), Chhattisgarh (Mohapattra et al. 2016), Andhra Pradesh (Kantimahanti et al. 2015), Maharashtra (Schulz 2013), West Bengal (Chowdhury et al. 2018), and a specimen sent to the Bombay Natural History Society Museum was recorded from Rajasthan (BNHS 3374) without precise locality data (Mohapattra et al. 2016; Chowdhury et al. 2018). Our observation provides precise locality data for the subspecies in Rajasthan.

\section{Acknowledgement}

The authors thank Dr. Harshil Patel for assistance in identifying the snake.

\section{Literature Cited}

Chowdhury, S., R. Sengupta, S. Mitra, and A. Chaudhuri. 2018. Extension of the known range of the Trinket Snake, Coelognathus helena nigriangularis (Reptilia: Squamata: Colubridae), in India. Reptiles \& Amphibians 25: 129-131.

Edake, S. 2011. Serpents of Bandhavgarh. The Corbett Foundation Newsletter October-December 2010 \& January-March 2011: 1-8.

Kantimahanti, M., K.D. Schulz, and V. Sharma. 2015. New locality records of Coelognathus helena cf. monticollaris (Schulz, 1992) from Andhra Pradesh,
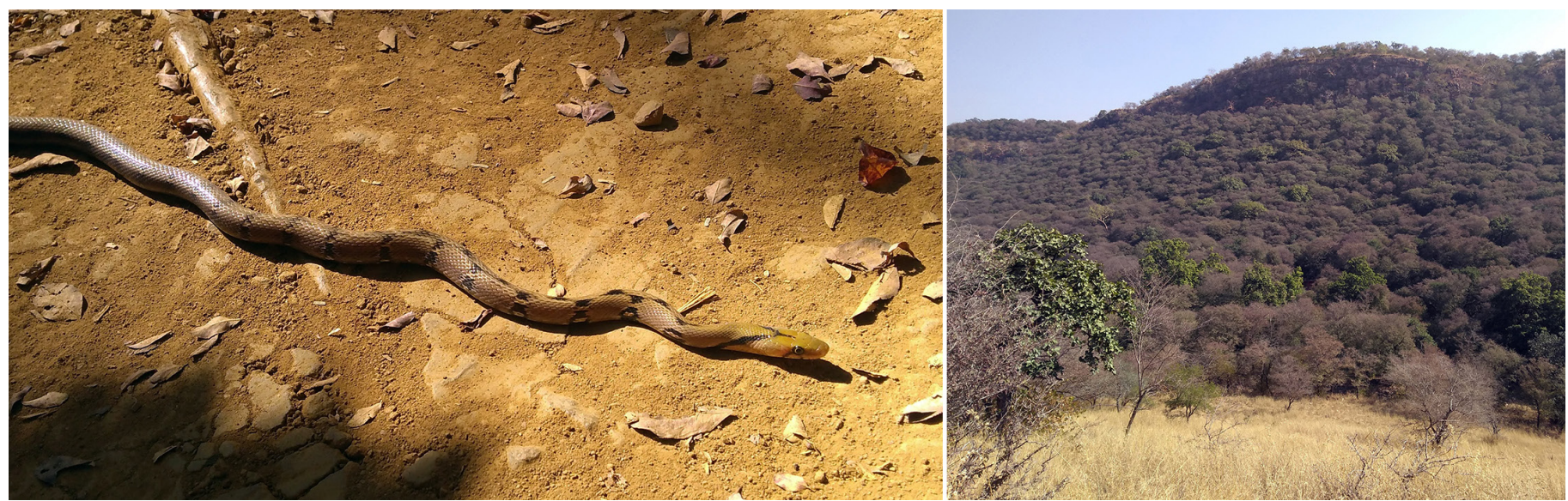

Fig. 1. An Arrow-headed Trinket Snake (Coelognathus helena nigriangularis) from the Ranthambore Tiger Reserve (left) and the habitat in which it was found (right). Photographs by Gaurav Singh. 
India. Sauria 37(4): 71-74.

Kumbhar A.S., G.C Patwardhan, A.K Pradhan, and N.S Dungriyal. 2011. New locality record of Coelognathus helena monticollaris (Schulz, 1992) from central India. Cobra 5(2): 31-35.

Lampe E. and W.A. Lindholm. 1902. Katalog der Reptilien- und AmphibienSammlung (Schlangen; Frosch-, Schwanz- und Schleichenlurche) des Naturhistorischen Museums zu Wiesbaden. Jahrbuch des Nassauischen Vereins für Naturkunde 55: 1-66.

Mohapattra, P.P., K.D. Schulz, N. Helfenberger, S. Hofmann, and S.K. Dutta.
2016. A contribution to Indian Trinket Snake, Coelognathus halena (Daudin 1803), with the description of new subspecies. Russian Journal of Herpetology 23: $115-144$.

Schulz, K.D. 2013. An annotated and illustrated checklist of Old World ratsnakes, pp. 17-268. In: K.D. Schulz (ed.), Old World Ratsnakes. A Collection of Papers. Bushmaster Publications, Berg, Switzerland.

Srivastava D.S., P.S Easa, and J.B Jauher. 2013. Integrated Wildlife Management Plan for Singhbhum, Jharkhand. Unpublished Report Submitted to the Department of Forest and Environment. Government of Jharkhand, India. 